\title{
Temporal fluctuations of nearshore ichthyoplankton off Valparaíso, central Chile, during the ENSO cycle 1997-2000
}

\author{
Fluctuaciones temporales del ictioplancton costero frente a Valparaíso, Chile central, \\ durante el ciclo ENOS 1997-2000 \\ Mauricio F. Landaeta ${ }^{1}$, Katherine Schrebler ${ }^{1}$, Claudia A. Bustos ${ }^{2,3}$, \\ Jaime Letelier ${ }^{4,5}$ and Fernando Balbontín ${ }^{1}$ \\ ${ }^{I}$ Facultad de Ciencias del Mar y de Recursos Naturales, Universidad de Valparaíso, Valparaíso, \\ Casilla 5080, Reñaca, Viña del Mar, Chile \\ ${ }^{2}$ CIEN Austral, Centro de Investigación en Nutrición, Tecnología de Alimentos y Sustentabilidad, \\ Universidad Austral de Chile sede Puerto Montt, Casilla 1327, Puerto Montt, Chile \\ ${ }^{3}$ Programa de Doctorado en Acuicultura, Universidad Católica del Norte, Coquimbo, Chile \\ ${ }^{4}$ Programa de Postgrado en Oceanografía, Departamento de Oceanografía, \\ Universidad de Concepción, Casilla 160-C, Concepción, Chile \\ ${ }_{5}^{5}$ Instituto de Fomento Pesquero, Blanco 893, Valparaíso, Chile \\ mauricio.landaeta@uv.cl
}

\begin{abstract}
Resumen.- Entre enero de 1997 y diciembre de 2000 se tomaron datos diarios de temperatura superficial del mar (TSM), altura del nivel del mar y transporte de Ekman, junto con muestreos quincenales y mensuales de ictioplancton en una estación costera ubicada en la bahía Valparaíso. Las muestras se recolectaron mediante lances verticales desde $50 \mathrm{~m}$ de profundidad hasta la superficie con una red cónica. De un total de 103 muestras, 71 tuvieron presencia de ictioplancton; se separó un total de 10.646 huevos y 1.189 larvas de peces, correspondiendo a 6 y 20 taxa, respectivamente. Las especies dominantes en los huevos fueron Engraulis ringens (35,5\%), Merluccius gayi (32,7\%) y Sardinops sagax (23,3\%). En las larvas dominaron M. gayi (53,5\%), S. sagax (16,1\%), E. ringens (13,7\%), Hygophum bruuni $(3,0 \%)$ y Prolatilus jugularis $(2,9 \%)$. Taxa específicos de huevos y larvas mostraron fluctuaciones en su abundancia a escala estacional y de acuerdo a las fases cálida y fría de El Niño-Oscilación del Sur (ENOS), similar a las observadas en las variables físicas. Aunque se encontraron fuertes diferencias en la abundancia de huevos durante el periodo, sólo los de $M$. gayi mostraron un incremento significativo durante La Niña. En el ciclo ENOS 1997-2000, la altura del nivel del mar y el transporte de Ekman mostraron fuertes diferencias entre las fases del ENOS, pero la diversidad total de la comunidad ictioplanctónica no fue afectada. No se detectaron diferencias significativas en los índices de diversidad, tanto en el índice de Shannon como en el de Simpson. Sin embargo, los análisis multivariados demostraron que las asociaciones de larvas estuvieron separadas significativamente de acuerdo a las fases cálida y fría del ENOS. Por lo tanto, la composición del ictioplancton fue afectada significativamente por el ciclo ENOS en la zona costera de Valparaíso entre 1997 y 2000.
\end{abstract}

Palabras clave: larvas de peces, estacionalidad, Engraulis ringens, Sardinops sagax

\begin{abstract}
Between January 1997 and December 2000 daily data of sea surface temperature, sea level height and Ekman transport were taken, together with biweekly and monthly sampling of ichthyoplankton in a coastal station located in Valparaíso Bay. Samples were collected through vertical tows from $50 \mathrm{~m}$ depth to surface with a conical net. From a total of 103 zooplankton samples, 71 samples had positive presence of ichthyoplankton; a total of 10,646 eggs and 1,189 larval fish were separated, corresponding to 6 and 20 taxa, respectively. Eggs specific composition was dominated by Engraulis ringens (35.5\%), Merluccius gayi $(32.7 \%)$ and Sardinops sagax $(23.3 \%)$. For larvae, dominant species were M. gayi $(53.5 \%)$, S. sagax (16.1\%), E. ringens (13.7\%), Hygophum bruuni (3.0\%) and Prolatilus jugularis (2.9\%). Specific taxa of both eggs and larvae showed fluctuations of their abundance at seasonal scale and according to the warm and cold phases of El Niño-Southern Oscillation (ENSO), similar to those observed in the physical time series data. Despite the strong differences in egg abundance in the period, only $M$. gayi eggs showed a significant increase during La Niña phase. In the ENSO 1997-2000 cycle, sea level height and Ekman transport showed strong differences between ENSO phases, but the whole diversity of the larval fish community was not affected. No significant differences in the diversity indices were detected, for Shannon index or for Simpson index. However, multivariate analyses showed that larval assemblages were significantly stratified according to the warm and cold phase of ENSO. Therefore, composition of ichthyoplankton was significantly affected by the ENSO cycle in the coastal area of Valparaíso between 1997 and 2000.
\end{abstract}

Key words: larval fish, seasonality, Engraulis ringens, Sardinops sagax 


\section{Introduction}

Physical processes at an interannual scale control environmental variability and together with seasonality of meteorology/oceanography and reproductive behaviour of fish determine the fluctuations in abundance and composition of early life stages of marine fish (Sánchez-Velasco et al. 2000, 2004, Franco-Gordo et al. 2004, Landaeta et al. 2008).

One of the most important processes at the interannual scale is the El Niño-Southern Oscillation (ENSO). During these events changes occur in sea-surface temperature, vertical thermal structure of the ocean (particularly in coastal regions), and coastal and upwelling currents. These changes may delay phytoplankton blooms, modify the abundance and distribution of invertebrates, affect species composition and abundance of macrozooplankton and fishes, and reduce fish catch (Funes-Rodríguez et al. 2006, Rojas-Méndez \& Robinson 2008).

In the Humboldt current ecosystem, the warm phase of ENSO (El Niño) deepens the thermocline, oxycline and nutricline, triggering variations in chlorophyll- $a$ concentration (González et al. 2000, Ulloa et al. 2001), community structure of copepods (Hidalgo \& Escribano 2001), and the abundance of several larval fish taxa (Rodríguez-Graña \& Castro 2003). Increases in immigrant marine fish species have also been observed during El Niño, with a correlation between thermal anomaly and number of species (Kong et al. 1985, Kong \& Bolados 1987, Sielfeld et al. 2002). Some key species such as the copepod Calanus chilensis exhibit greater abundances, higher growth rates and a significant reduction in adult body size, allowing them to cope with strong environmental perturbations such as the 19971998 El Niño event, the strongest on record (Ulloa et al. 2001).

On the other hand, the cold phase of ENSO (La Niña) is characterized by unusually cold ocean temperatures in the central and Eastern Pacific driven by stronger trade winds. Among other biological effects, La Niña affects the composition and abundance of seabird assemblages (Ribic et al. 1992), triggers an increase in the size of the female copepod C. chilensis (Escribano \& Hidalgo 2000), and negatively affects settlement of the black snail Tegula atra in southern Chile (Moreno 2004).

Most research into the biological impact of ENSO events has been restricted to the northern zone of Chile, and there is little knowledge about the bio-physical coupling of early life stages of marine fishes in the coastal area of central Chile (Hernández-Miranda \& Ojeda 2006). The main goal of this investigation was to establish the temporal variability of ichthyoplankton (eggs and larval fish) in a coastal station located at Valparaíso Bay during the warm and cold phases of the ENSO cycle 1997-2000, and to determine the effect of ENSO on the composition and abundance of early life stages of fish.

\section{Material and methods}

\section{Physical data}

Sea surface temperature (SST) data from January 1997 to December 2000 were taken daily at the monitoring coastal station of Valparaíso port from the Servicio Hidrográfico y Oceanográfico de la Armada de Chile (SHOA). Trends were extracted from the time series, and monthly averages were calculated. Daily information on sea level height at Valparaíso port was obtained from the Sea Level Center of Hawaii University ${ }^{1}$; and monthly averages were calculated. Wind data were extracted from a global regular grid of scateremeter ERS 2 satellite images (mean wind fields), distributed by CERSAT (Centre ERS d'Archivage et de Traitement) of IFREMER (French Research Institute for Exploitation of the Sea) ${ }^{2}$. Ekman transport was estimated from a time series with a spatial resolution of $0.5^{\circ}$ and a temporal monthly resolution (data centered on $33.5^{\circ} \mathrm{S}$ and $72.5^{\circ} \mathrm{W}$ ).

\section{Field work}

Between January 1997 and December 2000 biweekly and monthly sampling of ichthyoplankton was carried out in a coastal station located at $2 \mathrm{~km}$ off Montemar, Valparaíso Bay, central Chile ( $32^{\circ} 57^{\prime}$ S, $71^{\circ} 33^{\prime}$ W, Fig. 1) over an a motorboat. Samples were collected using vertical tows from $50 \mathrm{~m}$ depth to the surface with a conical net $(66-\mathrm{cm}$ diameter, $330 \mu \mathrm{m}$ mesh size) equipped with a TSK flowmeter to estimate filtered volumes of sea water. On recovery, the net was washed and the contents fixed with sodium borate buffered $5 \%$ formalin.

\section{Laboratory work and data analyses}

All eggs and larval fish were separated, counted and identified to the lowest taxonomic level according to Fischer (1958, 1959), Balbontín \& Garretón (1977), Balbontín \& Pérez (1979, 1980), Pérez (1979, 1981), Orellana \& Balbontín (1983), Olivar \& Fortuño (1991), Zuñiga \& Acuña (1992), and Landaeta et al. (2006). Larval fish were categorised according to adult habitat (epipelagic, mesopelagic, demersal and subtidal/ intertidal) and the egg and larval densities were standardised to individuals per $10 \mathrm{~m}^{2}$ following Smith \& Richardson (1977).

\footnotetext{
${ }^{1}$ http://uhslc.soest.hawaii.edu/

${ }^{2} \mathrm{http} / / / \mathrm{www}$. ifremer.fr/cersat/en/data/data.htm
} 


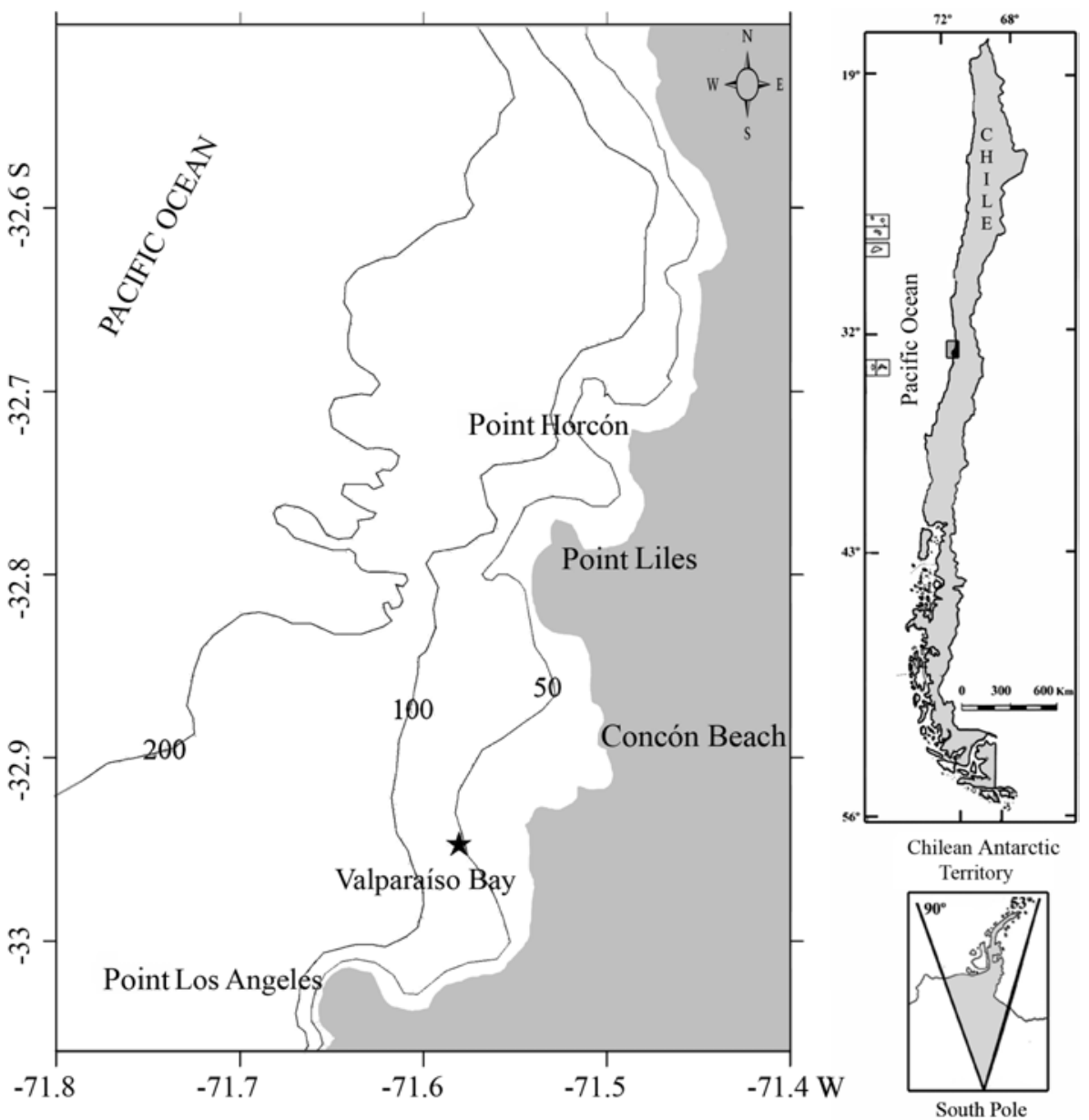

Figure 1

Study area, Valparaíso Bay, central Chile. A star indicates the sampling location, and bathymetry is presented in meters

Área de estudio, bahía de Valparaíso, Chile central. La estación de muestreo se indica con una estrella y la batimetría es presentada en metros

The Shannon-Wiener diversity index $\left(H^{\prime}\right)$ and Simpson diversity index $(1-\lambda)$ were used as measures of heterogeneity in the larval community. These indices express the number of species and uniformity in abundance of individuals of different species. A large number of species increases diversity (richness), but the same is true when abundance among them is uniform (evenness). These measures were applied to the standardised abundance during each sampling month. Pielou analysis of dominance $\left(J^{\prime}\right)$ was obtained by calculating maximum diversity of the Shannon-Wiener $\left(H_{\max }{ }^{\prime}\right)$. This index makes it possible to determine if, within a group of species, there exist a greater number of individuals in a reduced number of species. These indices and the abundance of selected taxa of eggs and larvae were then compared between the warm and cold phase of the ENSO during 1997-2000 by using the MannWhitney U test, because assumptions of normality were not achieved (Shapiro-Wilks W tests for all variables: $P$ $<0.05)$.

Larval fish assemblages were classified with a hierarchical cluster analysis using a Bray-Curtis dissimilarity matrix, which was calculated among species using standardised larval abundances of species with dominance $>0.5 \%$. Dominance corresponds to the sum of standardized values of fish larvae (individuals per 10 $\mathrm{m}^{2}$ ) of all samples taken during the studied period. The cut percentage of the cluster was determined calculating the average value of the dissimilarity matrix. To study the variability of larval fish assemblages during the ENSO 
cycle, standardised larval density was $\log (\mathrm{x}+1)$ transformed to enhance the contribution of less abundant taxa and a Bray-Curtis similarity matrix was generated from these data. Similarities between assemblages were graphically represented by non-metric multidimensional scaling (MDS, Cox \& Cox 2000) ordination. The degree of correspondence between the distances among points implied by MDS map and the matrix input was measured by a stress function. A one-way analysis of similarities (ANOSIM), which is analogous to univariate analysis of variance, was used to determine if assemblage groupings in the MDS ordination were significantly different from each other (Clarke 1993). Pairwise ANOSIM comparisons were made between groups, by using 10,000 permutations.

\section{Results}

Monthly time series of physical data showed seasonal and ENSO patterns (Fig. 2). For the SST and Ekman transport a seasonal pattern was noticeable. SST during austral winter 1997 was higher $\left(14.3^{\circ} \mathrm{C}\right)$ than winter 1998 $\left(12^{\circ} \mathrm{C}\right)$. Also, SST during summer 1998 and 1999 were higher than summer of 2000 (Fig. 2). High values of Ekman transport were evident during early spring and low values during early autumn. At inter-annual time scales, differences between winter and summer SST during El Niño (from January 1997 to May 1998) were lower than during La Niña (from September 1998 to December 2000), sea level height was also higher during the warm phase of ENSO (up to $95 \mathrm{~cm}$ ) than the cold phase $(<80 \mathrm{~cm})$. Ekman transport was lower and highly seasonal during El Niño off the Valparaíso area compared with the La Niña period. The increase of Ekman transport during autumn-winter $1999\left(\sim 50 \mathrm{~m}^{3} \mathrm{~s}^{-1}\right)$ was associated with an input of cold, dense water $\left(\sim 13^{\circ} \mathrm{C}\right)$ that reduced the sea level height during the period.

From a total of 103 zooplankton samples, 71 samples included ichthyoplankton during the study period (1997

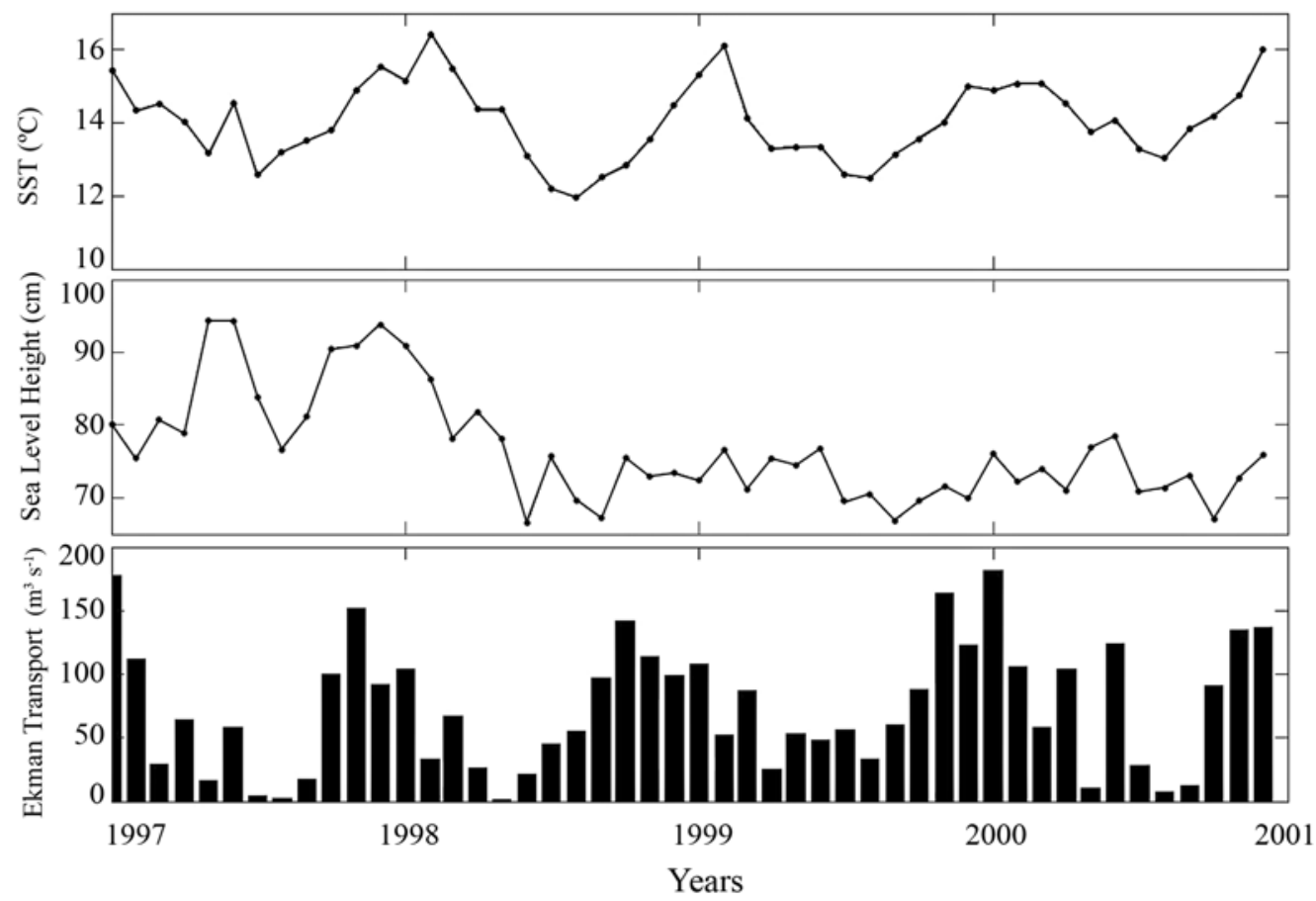

Figure 2

Time series of monthly-averaged daily data of sea surface temperature (SST, $\left.{ }^{\circ} \mathrm{C}\right)$, sea level height $(\mathrm{cm})$, and Ekman transport $\left(\mathrm{m}^{3} \mathrm{~s}^{-1}\right)$ off Valparaíso Bay, central Chile, between January 1997 and December 2000

Series de tiempo de datos diarios promediados mensualmente de temperatura superficial del mar (SST, $\left.{ }^{\circ} \mathrm{C}\right)$, altura del nivel del mar $(\mathrm{cm})$, y transporte de Ekman $\left(\mathrm{m}^{3} \mathrm{~s}^{-1}\right)$ frente a

la bahía de Valparaíso, Chile central, entre enero de 1997 y diciembre de 2000 
Table 1

Composition and abundance of fish eggs in a coastal station during the warm and cold phase of ENSO 1997-2000. Egg density expressed as individuals per $10 \mathrm{~m}^{2}$. SD $=$ one standard deviation

Composición y abundancia de huevos de peces en una estación costera durante la fase cálida y fría del ENOS 1997-2000. Densidad de huevos expresada como individuos por $10 \mathrm{~m}^{2}$. $\mathrm{SD}=$ una desviación estándar

\begin{tabular}{lcrrrrr}
\hline & \multicolumn{3}{c}{ El Niño 1997-1998 } & & \multicolumn{2}{c}{ La Niña 1999-2000 } \\
& Mean & SD & Median & Mean & SD & Median \\
\hline Engraulis ringens & 707.03 & 1065.00 & 296.57 & 2396.67 & 5964.41 & 170.80 \\
Sardinops sagax & 510.52 & 728.90 & 106.06 & 4248.43 & 11050.11 & 434.96 \\
Merluccius gayi & 411.81 & 451.27 & 247.47 & 2049.60 & 2908.25 & 843.57 \\
Paralichthys spp. & 411.41 & 512.73 & 250.09 & 322.73 & 407.58 & 151.52 \\
Hippoglossina macrops & 56.54 & 51.37 & 36.57 & 50.05 & 37.67 & 44.45 \\
Scomberesox saurus & 39.14 & - & 39.14 & 18.76 & - & 18.76
\end{tabular}

\section{Table 2}

Composition and abundance of larval fish in a coastal station during the warm and cold phase of ENSO 1997-2000. Larval density expressed as individuals per $10 \mathrm{~m}^{2}$.

$$
\text { SD }=\text { one standard deviation }
$$

Composición y abundancia de larvas de peces en una estación costera durante la fase cálida y fría del ENOS 1997-2000. Densidad larval expresada como individuos por $10 \mathrm{~m}^{2}$.

$\mathrm{SD}=$ una desviación estándar

\begin{tabular}{|c|c|c|c|c|c|c|}
\hline & & $\mathrm{El} \mathrm{Ni}$ & $97-1998$ & & La Niña & $999-2000$ \\
\hline & Mean & SD & Median & Mean & SD & Median \\
\hline Epipelagic & & & & & & \\
\hline Engraulis ringens & 131.08 & 135.70 & 65.05 & 539.83 & 537.64 & 581.41 \\
\hline Sardinops sagax & 253.96 & 252.02 & 177.94 & 69.27 & 35.49 & 80.07 \\
\hline Ethmidium maculatum & 36.22 & 14.09 & 36.22 & - & - & - \\
\hline Normanichthys crockeri & - & - & - & 47.45 & - & 47.45 \\
\hline Oceanic & & & & & & \\
\hline Diogenichthys atlanticus & 38.49 & 18.52 & 42.24 & 24.90 & 8.88 & 19.77 \\
\hline Diogenichthys laternatus & - & - & - & 24.97 & - & 24.97 \\
\hline Hygophum bruuni & 30.72 & 18.18 & 26.15 & 48.91 & 37.39 & 32.72 \\
\hline Nannobrachium sp. & 51.32 & - & 51.32 & 27.90 & 21.56 & 27.90 \\
\hline Protomyctophum chilensis & 26.89 & - & 26.89 & 18.76 & - & 18.76 \\
\hline Triphoturus oculeus & 28.72 & - & 28.72 & - & - & - \\
\hline Seriolella sp. & 147.83 & 154.90 & 147.83 & 90.80 & 5.80 & 90.80 \\
\hline Demersal & & & & & & \\
\hline Merluccius gayi & 425.16 & 660.97 & 157.57 & 291.47 & 414.06 & 82.52 \\
\hline Sebastes capensis & 100.54 & 116.32 & 100.54 & 23.73 & - & 23.73 \\
\hline Genypterus sp. & 86.17 & - & 86.17 & 22.93 & 5.91 & 22.93 \\
\hline Hippoglossina macrops & 47.01 & 14.76 & 47.01 & 23.75 & 3.04 & 24.33 \\
\hline Subtidal-Intertidal & & & & & & \\
\hline $\begin{array}{l}\text { Helcogrammoides } \\
\text { chilensis }\end{array}$ & 18.17 & - & 18.17 & 26.13 & 4.99 & 26.13 \\
\hline Hypsoblennius sordidus & 26.89 & - & 26.89 & 30.06 & 11.42 & 24.97 \\
\hline Prolatilus jugularis & 191.49 & - & 191.49 & 71.18 & - & 71.18 \\
\hline Paralichthys sp. & 64.73 & 39.29 & 57.66 & - & - & - \\
\hline Scartichthys sp. & 64.24 & 47.52 & 64.24 & 21.64 & 6.86 & 21.09 \\
\hline Unidentified taxa & 29.20 & 9.60 & 33.00 & 65.68 & 43.42 & 57.28 \\
\hline
\end{tabular}


to 2000); a total of 10,646 eggs and 1,189 larval fish were collected, corresponding to 6 and 20 taxa respectively (Tables 1 and 2). For the entire period, eggs were dominated by 'anchoveta' Engraulis ringens (35.5\%), hake Merluccius gayi (32.72\%) and sardine Sardinops sagax (23.29\%). For larvae, dominant species were $M$. gayi (53.48\%), S. sagax (16.09\%), E. ringens (13.70\%), myctophid Hygophum bruuni $(3.04 \%)$ and sandperch Prolatilus jugularis (2.96\%). Specific taxa of both eggs and larvae showed fluctuations of their standardised abundance at both seasonal and ENSO scale. During El Niño 1997-1998, eggs were more abundant during the austral summer and autumn (Fig. 3). At the beginning of the cold phase of ENSO, there was an abrupt increase in the abundance of $M$. gayi eggs. A peak of $E$. ringens eggs occurred during winter 1999, and spring 1999, with the highest densities of $E$. ringens, $S$. sagax and M. gayi eggs collected (Fig. 3). In contrast, the density of Paralichthys spp. eggs varied seasonally, with higher peaks during mid summer, early autumn, and early spring. Despite the strong difference in egg abundance during the period, only $M$. gayi eggs showed a significant increase during the La Niña phase (Mann-Whiney U test, $\mathrm{U}=160, P=0.025)$.

For the most dominant larval fish, two temporal patterns were evident (Fig. 4). The species group, including $S$. sagax and Paralichthys spp., showed a density peak during later summer 1997, and then a reduced abundance during the rest of the study period. Other taxa, like E. ringens, H. bruuni and Hypsoblennius sordidus, showed reduced abundance or were almost absent during El Niño, but during La Niña increased two to three times in late austral winter and early spring 1999 (Fig. 4). Larvae of M. gayi showed a decreasing trend in density throughout the studied period. However, none of the taxa showed significant differences in their densities (Mann-Whiney U test, $P>0.1$ ).

Overall density of larval fish community was not affected by the ENSO 1997-2000 cycle. No significant differences in dominance or diversity indices were detected (Shannon index, $\mathrm{U}=130.5, P=0.677$; Simpson index, $\mathrm{U}=137, P=0.848$; and Pielou index, $\mathrm{U}=137, P$ $=0.356)($ Table 3$)$.
El Niño

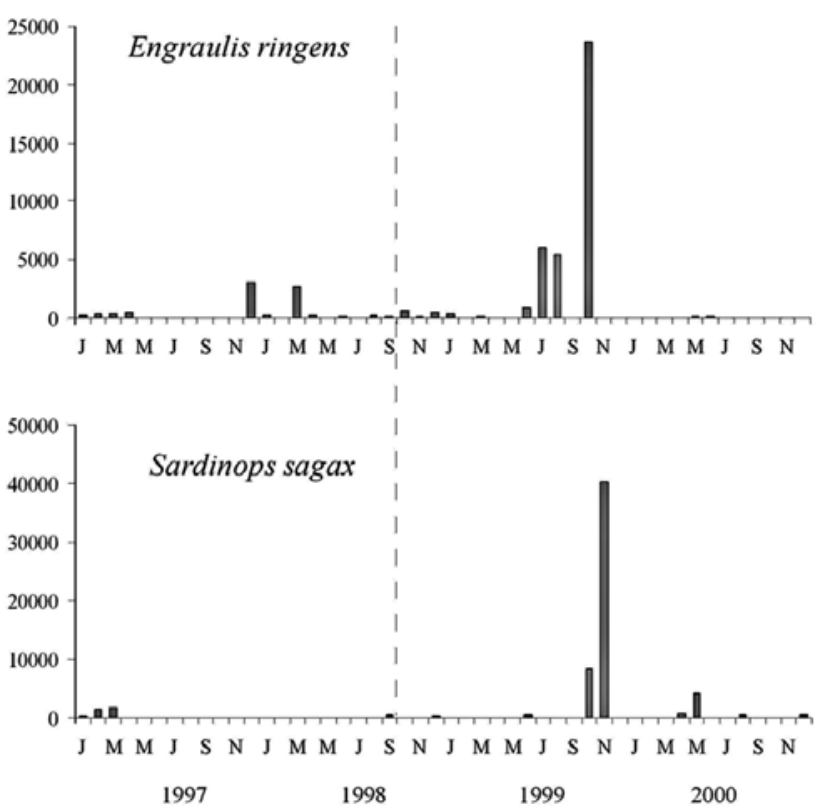

El Niño

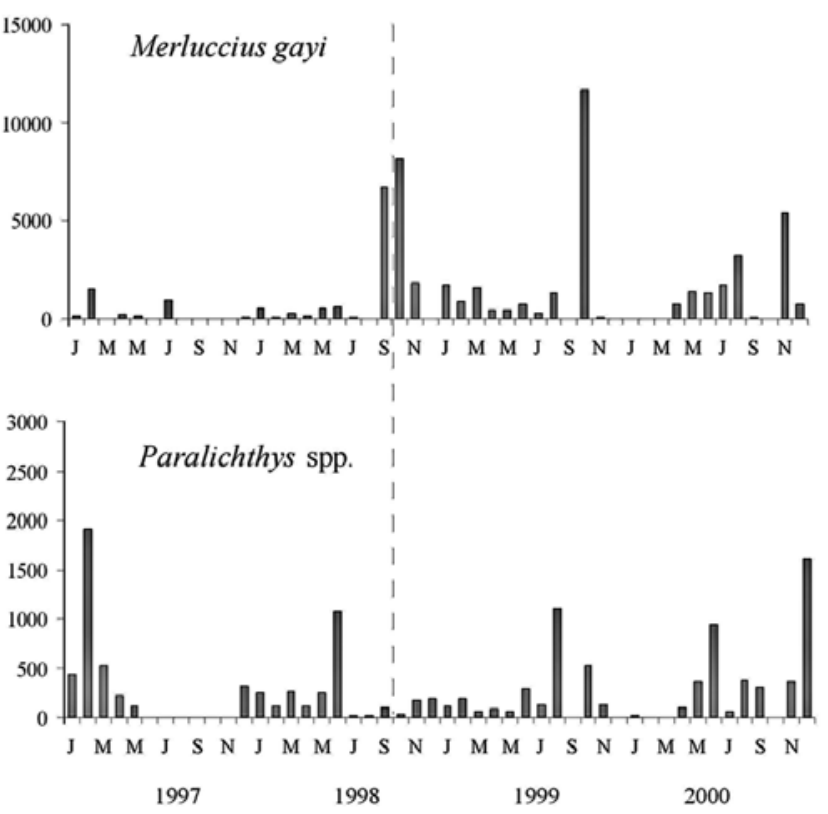

Figure 3

Temporal series of fish eggs abundance (individuals per $10 \mathrm{~m}^{2}$ ) captured at a coastal station between January 1997 and December 2000 off Valparaíso

Serie temporal de abundancia de huevos de peces (individuos por $10 \mathrm{~m}^{2}$ ) capturados en una estación costera entre enero de 1997 y diciembre de 2000 frente a Valparaíso 

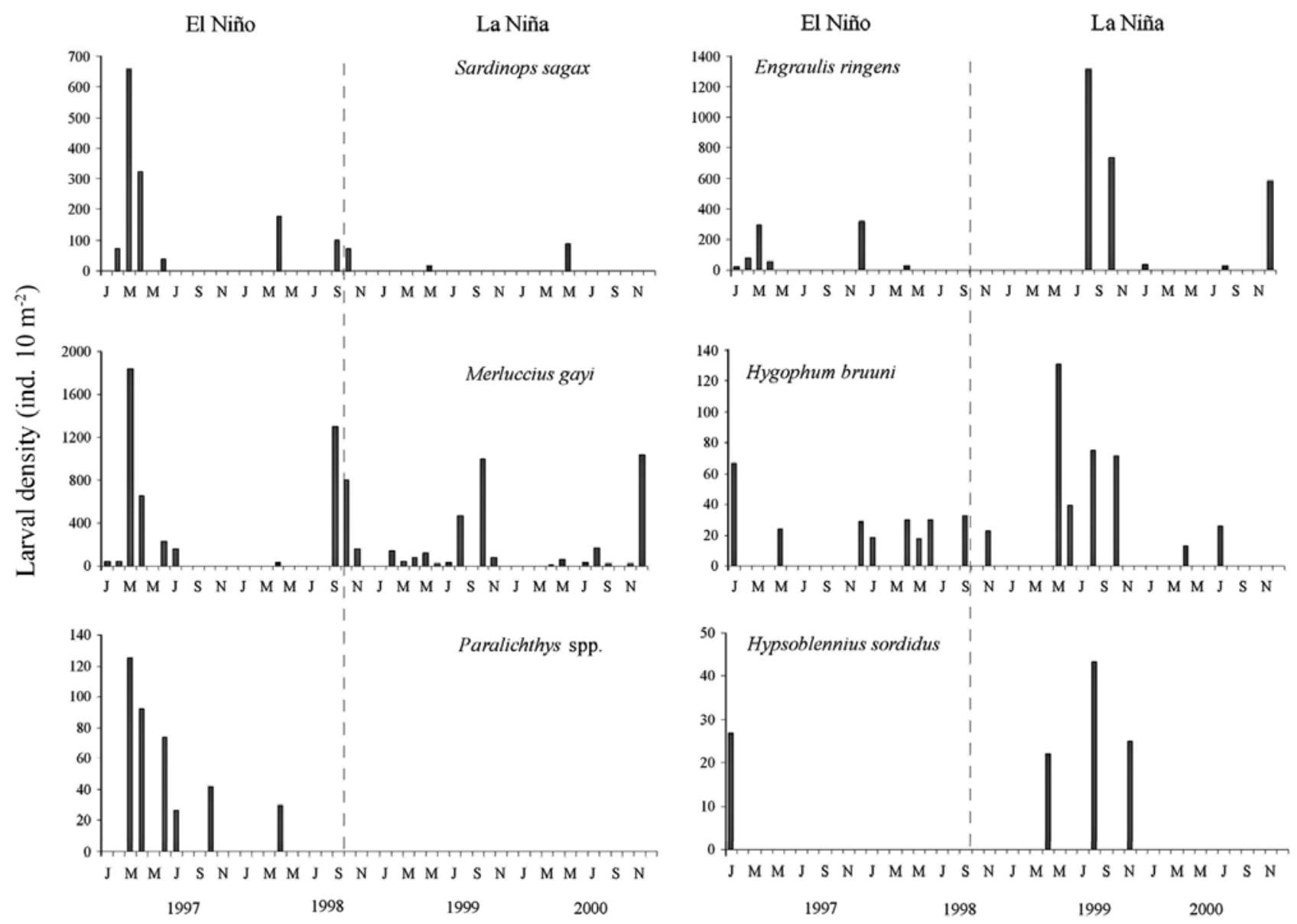

Figure 4

Temporal series of specific taxa of larval fish abundance (individuals per $10 \mathrm{~m}^{2}$ ) captured at a coastal station between 1997 and 2000 off Valparaíso

Serie temporal de taxa específicos de abundancia de larvas de peces (individuos por $10 \mathrm{~m}^{2}$ ) capturadas en una estación costera entre enero de 1997 y diciembre de 2000 frente a Valparaíso

Table 3

Synopsis of the indices of larval community during both phases of ENSO 1997-2000 off Valparaíso. SD = one standard deviation

Sinopsis de los índices de comunidad larval durante ambas fases del ENSO 1997-2000 frente a Valparaíso. SD = una desviación estándar

\begin{tabular}{llclr}
\hline & \multicolumn{2}{c}{ El Niño } & \multicolumn{2}{c}{ La Niña $1999-2000$} \\
& Mean & SD & Mean & SD \\
\hline Shannon-Wiener diversity index & 1.034 & 0.541 & 0.874 & 0.282 \\
Simpson diversity index & 0.527 & 0.212 & 0.523 & 0.129 \\
Pielou dominance index & 0.735 & 0.216 & 0.810 & 0.177 \\
\hline
\end{tabular}




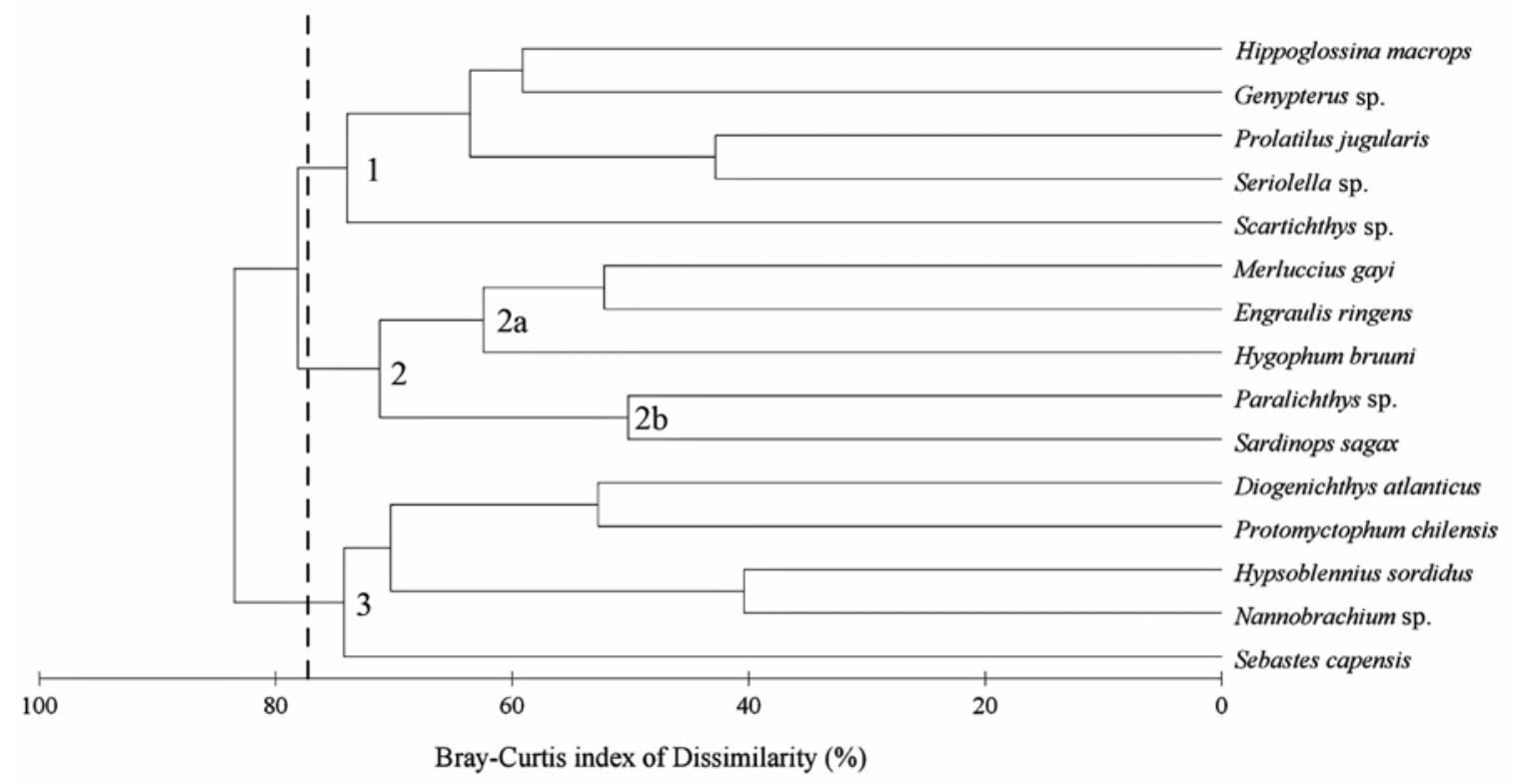

Figure 5

Cluster analysis of dominant larval fish species during the 1997-2000 ENSO cycle. Numbers correspond to the identified ichthyoplanktonic assemblages

Análisis de dendrogramas de larvas de peces más abundantes durante el ciclo ENOS 1997-2000.

Los números indican las asociaciones ictioplanctónicas identificadas

Over the entire time series, three larval assemblages were defined at a 77\% dissimilarity level (Fig. 5): bigeye flounder Hippoglossina macrops, Genypterus sp., Prolatilus jugularis, warehou Seriolella sp. and Scartichthys sp. composed a demersal-intertidal assemblage. Abundance of these species increased during the ENSO warm phase. The second larval assemblage included the dominant taxa: a first subgroup which was more abundant during La Niña (Merluccius gayi, Engraulis ringens and Hygophum bruuni) and a second subgroup that appeared mostly during El Niño phase (Paralichthys sp. and Sardinops sagax). The third larval assemblage comprised mesopelagic and subtidal species, including Diogenichthys atlanticus, Protomyctophum chilensis, Nannobrachium sp., blenniid Hypsoblennius sordidus and rockfish Sebastes capensis. Larvae of Ethmidium maculatum, Diogenichthys laternatus, Triphoturus oculeus, Normanichthys crockeri and Helcogrammoides chilensis were not included in the cluster analysis due to their low relative abundance. The structure of larval fish throughout the sampled period showed some grade of overlapping according to the warm and cold phase of ENSO in the MDS plot (Fig. 6); however, ANOSIM revealed this difference was significant (global $\mathrm{R}=0.197, P<0.01$ ).

\section{Discussion}

Analysis of the ichthyoplankton eggs and larvae time series showed two temporal patterns, one associated with seasonal abundances, and another related to the variability of larval fish assemblages during the warm and cold phase of the ENSO cycle.

Changes in the composition and abundance of fish eggs and larval fish have been observed in the Humboldt Current ecosystem during transitional periods (late summer and winter). For instance, Hernández-Miranda et al. (2003) showed increases in the fish egg abundance during September 1999 (late winter-early spring) and March 2000 (late summer-early autumn) in coastal areas off Las Cruces, central Chile. Also, they found seasonal 


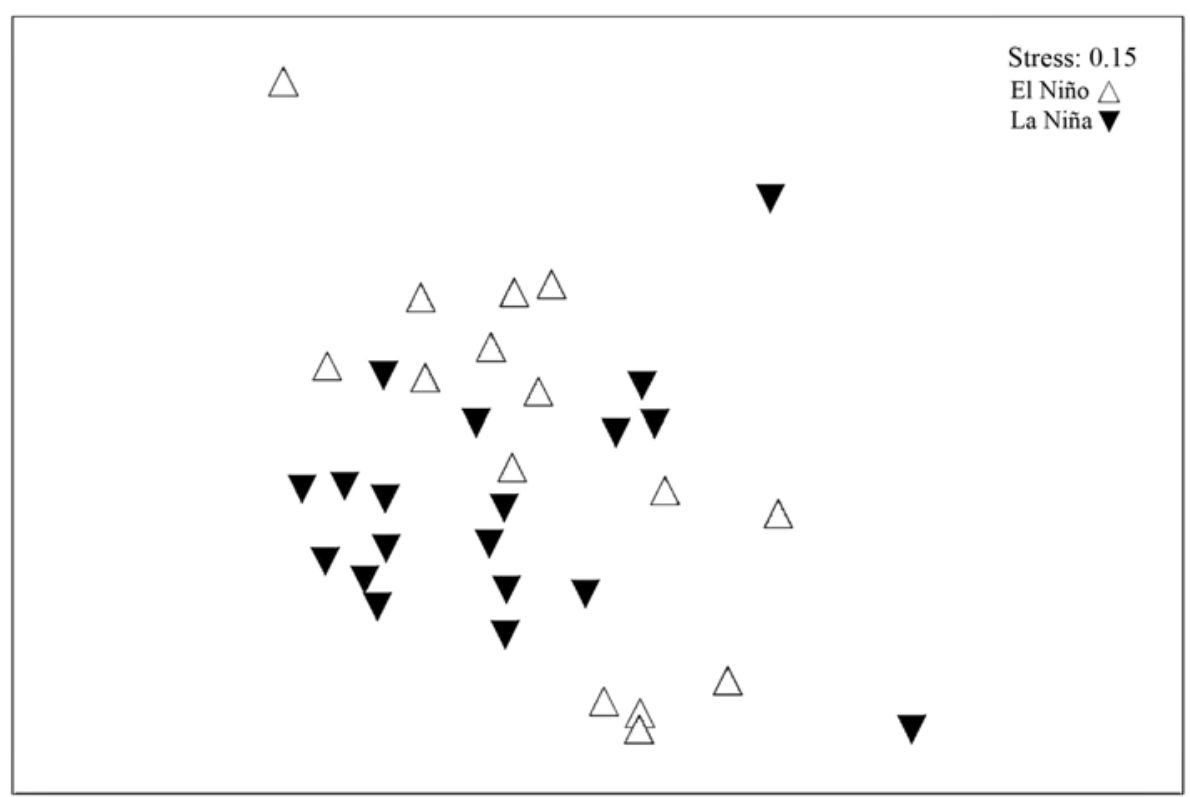

Figure 6

\begin{abstract}
Non-metric multi-dimensional scaling ordination plot of log-transformed abundance data. Stress value is given in the top right corner of the plot. $(\triangle)$ - El Niño samples and $(\boldsymbol{\nabla})$ - La Niña samples
\end{abstract}

Gráfico de ordenación de datos de abundancia log-transformados utilizando escalamiento no métrico multidimensional. El valor de estrés está dado en la esquina derecha del gráfico. $(\triangle)$ - muestras de El Niño y $(\boldsymbol{\nabla})$ - muestras de La Niña

variability in the abundance of epipelagic and mesopelagic larval fish in the same area. Similar changes in larval fish assemblages have been observed at seasonal scales in nearshore zones off Perú $\left(14^{\circ} \mathrm{S}\right.$ ) (Vélez et al. 2005), Valparaíso (33ㅇ) (Balbontín \& Bravo 1999), Talcahuano $\left(37^{\circ} \mathrm{S}\right)$ (Landaeta et al. 2008) and southern Chile $\left(41-46^{\circ} \mathrm{S}\right)$ (Landaeta \& Castro 2006b, Bustos et al. 2008).

The seasonality of the abundance of both eggs and larval fish during transitional seasons are mainly linked to reproductive behavior of adult population and the phase of their life cycle, which in turn is often associated with oceanographic and meteorological features. During transitional periods, the south eastern Pacific subtropical anticyclone moves, producing high wind variability associated with frontal disturbances and coastal lows (Rutllant et al. 2004). The high variability in wind speed and direction may reduce the offshore advection of the surface Ekman layer, increasing the residence time of surface planktonic organisms near headlands in coastal areas (Palma et al. 2006), where feeding success and growth of early life stages of fishes are high (HernándezMiranda et al. 2003, Landaeta \& Castro 2006a). However, these seasonal trends can be affected by physical processes occurring at larger temporal scales, such as interannual signals like El Niño and La Niña events.

The ENSO cycle 1997-2000 was characterized by an increase of $4-5^{\circ} \mathrm{C} \mathrm{SST} \mathrm{during} \mathrm{El} \mathrm{Niño} \mathrm{and} \mathrm{a} \mathrm{decrease} \mathrm{of}$ 2 to $3^{\circ} \mathrm{C}$ during La Niña, together with variations in the chlorophyll- $a$ concentration in coastal areas of central Chile (Bello \& Maturana 2004, Hernández-Miranda \& Ojeda 2006). Off Valparaíso, a decrease of wind intensity triggered a reduction in the offshore Ekman transport during El Niño, which in turn reduced the upwelling of colder waters to the coastal area, increased sea level height, and elevated SST. The presence of warmer waters in coastal areas off Valparaíso may have been caused not only by entrance of warm waters from the north, but also by local warming of coastal water parcels due to the decreased upwelling activity. In contrast, during La Niña 
there was an increase of surface offshore Ekman transport throughout 1999 and 2000, which increased the upwelling of colder and denser waters, reduced sea level height, and lowered SST during the austral summer of 2000.

This strong event not only affected abundance, composition and reproductive output of epipelagic, oceanic, and demersal fish (Table 2, Funes-Rodríguez et al. 2006), but also affected somatic growth and mortality rates of intertidal fishes (Hernández-Miranda \& Ojeda 2006). Other components of the plankton were also affected. For instance, Hidalgo \& Escribano (2001) observed an increase in the number of the dominant herbivorous copepods, Calanus chilensis, during El Niño in northern Chile. They did not find significant differences in the diversity of pelagic copepods between El Niño and non-El Niño periods, probably because the contribution of expatriate species compensated for the decrease in abundance of some resident species. A similar explanation may be given for the lack of differences in the larval community diversity and dominance indices calculated between El Niño and La Niña phases in the Valparaíso zone. For instance, larval flounder Paralichthys spp. were found only during El Niño months, but mote sculpin Normanichthys crockeri larvae were only collected during La Niña period.

In this time series, among larval fish with epipelagic adults, larvae of sardine $S$. sagax showed higher densities during the beginning of 1997 in the warm phase of ENSO. In constrast, larval anchoveta $E$. ringens were collected in higher abundance during La Niña. However, observation in the north Pacific showed the opposite trend (Sánchez-Velasco et al. 2000; Franco-Gordo et al. 2004) during the same ENSO event. While larval sardine $S$. caeruleus were almost absent during the warm phase, when SST increased by $4^{\circ} \mathrm{C}$, Engraulis mordax larvae were recorded in high abundance (>100 larvae per 10 $\mathrm{m}^{2}$ ). After the event, larval $S$. caeruleus increased in abundance. More information is needed to understand and interpret such differences in occurrence patterns of those two epipelagic larvae.

Mesopelagic larvae such as Vinciguerria lucetia and Benthosema panamense and carangid larvae (Caranx sp. and Auxis sp.), also showed a significant increase in their abundance during ENSO 1997-98 along the central Pacific coast of Mexico and Australia. According to Franco-Gordo et al. (2004) and Sampey et al. (2004), a tropicalization of the species composition during the El Niño event occurred in tropical and subtropical areas. In the coastal area off Valparaíso Bay, excepting for $H$. bruuni, most mesopelagic larvae were more abundant during the El Niño than La Niña, and some species were replaced between phases (e.g. Triphoturus oculeus was collected only during El Niño, but Diogenichthys laternatus was collected only during La Niña). The alteration in the composition of larval mesopelagic taxa has also been detected off Baja California during ENSO events. Recently, Funes-Rodríguez et al. (2006) suggested that tropical species such as Diplophos proximus, Diaphus pacificus and Benthosema panamense larvae were indicative of the El Niño 1982-1984 event in the California Current; this assemblage was replaced by mesopelagic larval fishes of temperate affinity (i.e. Symbolophorus, Melamphaes, Bathylagus, Protomyctophum crockeri) during the normal period, from mid 1984 to mid 1987.

Throughout our study, larval hake was the dominant taxon. The Valparaíso area has been identified as one of the most important spawning areas of Merluccius gayi in Chile (Bernal et al. 1997, Balbontín \& Bravo 1999, Vargas \& Castro 2001). Although spawning of the Chilean hake may occur offshore in the vicinity of the shelf-break (Vargas \& Castro 2001), during certain periods adult hake reproduce near the coast $(<8 \mathrm{~km}$ from shore, Bernal et al. 1997, Landaeta \& Castro 2006a). Our data also showed that highest larval densities of M. gayi were collected at the onset and the end of the El Niño phase, but during La Niña, larval hake appeared more frequently in the samples; the highest value of larval abundance obtained during this cold period occurred when Ekman transport was low. Bernal et al. (1997) showed that larval hake were most abundant associated to cold waters and moderate upwelling indices off Valparaíso area; a similar trend has also been detected for larval Merluccius productus off Baja California between 1951 and 2001 (Funes-Rodríguez et al. 2009). The presence of colder surface waters in coastal areas, either as a result of upwelling events and/or by La Niña may affect the abundance of this key species through a still unknown bio-physical coupling.

In sum, the information presented here shows that the physical processes associated with large-scale event like El Niño and La Niña may exert an influence on the composition and abundance of larval fish in coastal areas of central Chile, affecting the seasonal trends of reproduction and spawning of marine fishes.

\section{Acknowledgments}

We thank the comments of three referees which improved the quality of the manuscript. This work was funded by project DIPUV44/2006 'Fluctuations of ichthyoplankton during seasonal transition period: effect of environmental variability off central Chile', adjudicated to FB \& MFL. 
During the writing of this manuscript, $\mathrm{CAB}$ was funded by a doctoral fellowship CONICYT, FNDR program of Gobierno Regional de Los Lagos, BIP: 30038191-0 and Programa Regional CONICYT: R04I1003. This work is dedicated to the memory of Professor Ismael Kong.

\section{Literature cited}

Balbontín F \& R Bravo. 1999. Distribución, abundancia y agrupaciones del ictioplancton en un área de desove de merluza común frente a Valparaíso. Revista de Biología Marina y Oceanografía 34(2): 233-260.

Balbontín F \& M Garretón. 1977. Desove y primeras fases de desarrollo de la sardina española, Sardinops sagax musica, en Valparaíso. Revista de Biología Marina 16: 171181.

Balbontín F \& R Pérez. 1979. Modalidad de postura, huevos y estados larvales de Hypsoblennius sordidus (Bennett) en la bahía de Valparaíso (Blenniidae: Perciformes). Revista de Biología Marina 16: 311-318.

Balbontín F \& R Pérez. 1980. Descripción de los estados larvales de Normanichthys crockeri Clark (Perciformes: Normanichtyidae) del área de Valparaíso. Revista de Biología Marina 17: 81-95.

Bello M \& J Maturana. 2004. Condiciones oceanográficas frente a Valparaíso durante la fase fría del ciclo ENOS 19972000. En: Avaria S, J Carrasco, J Rutllant \& E Yáñez (eds). El Niño-La Niña 1997-2000, sus efectos en Chile, pp. 2942. CONA, Valparaíso.

Bernal R, F Balbontín \& O Rojas. 1997. Patrones de distribución de huevos y larvas de Merluccius gayi gayi en la costa de Chile y factores ambientales asociados. Revista de Biología Marina y Oceanografía 32(1): 45-66.

Bustos CA, MF Landaeta \& F Balbontín. 2008. Efectos ambientales sobre la variabilidad espacial del ictioplancton de Chile austral durante noviembre de 2005. Revista Chilena de Historia Natural 81: 205-219.

Clarke KR. 1993. Non-parametric multivariate analyses of change in community structure. Australian Journal of Ecology 18: 117-143.

Cox TF \& MAA Cox. 2000. Multidimensional scaling. Monographs on Statistics and Applied Probability 88, 328 pp. Chapman \& Hall/ CRC, Boca Raton.

Escribano R \& P Hidalgo. 2000. Influence of El Niño and La Niña on the population dynamics of Calanus chilensis in the Humboldt Current ecosystem of northern Chile. ICES Journal of Marine Science 57: 1867-1874.

Fischer W. 1958. Primeras fases del desarrollo del blanquillo (Prolatilus jugularis) Cuv. et al. (Pisces). Revista de Biología Marina 8: 3-24.

Fischer W. 1959. Huevos, crías y prelarvas de la merluza. Revista de Biología Marina 9: 229-249.
Franco-Gordo C, E Godínez-Domínguez, AE Filonov, IE Tereshchenko \& J Freire. 2004. Plankton biomass and larval fish abundance during El Niño 1997-1998 period along the central Pacific coast of México. Progress in Oceanography 63: 99-123.

Funes-Rodríguez R, JF Elorduy-Garay, A Hinojosa-Medina \& A Zárate-Villafranco. 2009. Interannual distribution of Pacific hake Merluccius productus larvae in the southern part of the California Current. Journal of Fish Biology 75: 630-646.

Funes-Rodríguez R, A Hinojosa-Medina, G Aceves-Medina, SPA Jiménez-Rosenberg \& JJ Bautista-Romero. 2006. Influences of El Niño on assemblages of mesopelagic fish larvae along the Pacific coast of Baja California Sur. Fisheries Oceanography 15(3): 244-255.

González HE, M Sobarzo, D Figueroa \& E-M Nöthig. 2000. Composition, biomass and potencial grazing impact of the crustacean and pelagic tunicates in the Northern Humboldt Current area off Chile: differences between El Niño and non-El Niño years. Marine Ecology Progress Series 195: 201-220.

Hernández-Miranda E \& FP Ojeda. 2006. Inter-annual variability in somatic growth rates and mortality of coastal fishes off central Chile: an ENSO driven process? Marine Biology 149: 925-936.

Hernández-Miranda E, AT Palma \& FP Ojeda. 2003. Larval fish assemblages in nearshore coastal waters off central Chile: temporal and spatial patterns. Estuarine, Coastal and Shelf Science 56: 1075-1092.

Hidalgo P \& R Escribano. 2001. Succession of pelagic copepod species in coastal waters off northern Chile: the influence of the 1997-98 El Niño. Hydrobiologia 453/454: 153-160.

Kong I \& B Bolados. 1987. Sinopsis de peces asociados al fenómeno El Niño 1982-83 en el norte de Chile. Estudios Oceanológicos 6: 25-58.

Kong I, KC Tomicic \& LJ Zegers. 1985. Ichthyofauna associated to the 1982-1983 El Niño phenomenon in the northern of Chile. Investigación Pesquera, (Chile) 32: 215224.

Landaeta MF \& LR Castro. 2006a. Spawning and larval survival of the Chilean hake Merluccius gayi under later summer conditions in the Gulf of Arauco, central Chile. Fisheries Research 77: 115-121.

Landaeta MF \& LR Castro. 2006b. Variabilidad estacional en los patrones espaciales de las asociaciones ictioplanctónicas de la zona de fiordos de Chile austral. Ciencia y Tecnología del Mar 29(2): 107-127.

Landaeta MF, R Veas, J Letelier \& LR Castro. 2008. Larval fish assemblages off central Chile upwelling ecosystem. Revista de Biología Marina y Oceanografía 43(3): 569584. 
Landaeta MF, GA Herrera, M Pedraza, CA Bustos \& LR Castro. 2006. Reproductive tactics and larval development of bigeye flounder, Hippoglossina macrops, off central Chile. Journal of Marine Biological Association of the United Kingdom 86: 1253-1264.

Moreno CA. 2004. Efectos de El Niño en el reclutamiento de Concholepas concholepas y Tegula atra (Mollusca: Gastropoda) en la costa de Valdivia, Chile. En: Avaria S, J Carrasco, J Rutllant \& E Yáñez (eds). El Niño-La Niña 1997-2000, sus efectos en Chile, pp. 179-189. CONA, Valparaíso.

Olivar M \& J Fortuño. 1991. Guide to ichthyoplankton of the Southeast Atlantic (Benguela Current Region). Scientia Marina 55: 1-383.

Orellana M \& F Balbontín. 1983. Estudio comparativo de las larvas de Clupeiformes de la costa de Chile. Revista de Biología Marina 19: 1-46.

Palma AT, LM Pardo, R Veas, C Cartes, M Silva, K Manríquez, A Díaz, C Muñoz \& FP Ojeda. 2006. Coastal brachyuran decapods: settlement and recruitment under contrasting coastal geometry conditions. Marine Ecology Progress Series 316: 139-153.

Pérez R. 1979. Desarrollo postembrionario de Tripterygion chilensis Cancino 1955, en la bahía de Valparaíso (Tripterygiidae: Perciformes). Revista de Biología Marina 16: 319-329.

Pérez R. 1981. Desarrollo embrionario y larval de los pejesapos Sycyases sanguineus y Gobiesox marmoratus en la bahía de Valparaíso, Chile, con notas sobre su reproducción (Gobiesocidae: Pisces). Investigaciones Marinas 9: 1-24.

Ribic CA, DG Ainley \& LB Spear. 1992. Effects of El Niño and La Niña on seabird assemblages in the Equatorial Pacific. Marine Ecology Progress Series 80: 109-124.

Rojas-Méndez JA \& CJ Robinson. 2008. Effects of ENSO 1997-1998 on the distribution of small pelagic fish off the west coast of Baja California. International Journal of Environment and Health 2(1): 45-63.

Rodríguez-Graña L \& LR Castro. 2003. Ichthyoplankton distribution off the Peninsula de Mejillones, Chile $\left(23^{\circ} \mathrm{S}\right.$, $71^{\circ} \mathrm{W}$ ), under variable hydrographic conditions during the austral summer and winter of the 1997 El Niño. Hydrobiologia 501: 59-73.
Rutllant JA, B Rosenbluth \& S Hormazábal. 2004. Intraseasonal variability of wind-forced coastal upwelling off central Chile $\left(30^{\circ} \mathrm{S}\right)$. Continental Shelf Research 24: 789-804.

Sampey A, MG Meekan, JH Carleton, AD McKinnon \& MI McCormick. 2004. Temporal patterns in distributions of tropical fish larvae on the North West Shelf of Australia. Marine and Freshwater Research 55(5): 473-487.

Sánchez-Velasco L, C Avalos-García, M Rentaría-Cano \& B Shirasago. 2004. Fish larvae abundance and distribution in the central Gulf of California during strong environmental changes (1997-1998 El Niño and 1998-1999 La Niña). Deep Sea Research II: 711-722.

Sánchez-Velasco L, B Shirasago, MA Cisneros-Mata \& C Avalos-García. 2000. Spatial distribution of small pelagic fish larvae in the Gulf of California and its relation to the El Niño 1997-1998. Journal of Plankton Research 22(8): 1611-1618.

Sielfeld W, M Vargas, V Berrios \& G Aguirre. 2002. Warm ENSO events and their effects on the coastal fish fauna of northern Chile. Investigaciones Marinas 30(suppl. 1): 122124.

Smith PE \& SL Richardson. 1977. Standard techniques for pelagic fish eggs and larvae. FAO Fisheries Technical Paper 175: 1-107.

Ulloa O, R Escribano, S Hormazábal, RA Quiñones, RR González \& M Ramos. 2001. Evolution and biological effects of the 1997-1998 El Niño in the upwelling ecosistema off Northern Chile. Geophysical Research Letters 28(8): 1591-1594.

Vargas CA \& LR Castro. 2001. Spawning of the Chilean hake (Merluccius gayi) in the upwelling system off Talcahuano in relation to oceanographic features. Scientia Marina 65(2): 101-110.

Vélez JA, W Watson, W Arntz, M Wolff \& SB SchnackSchiel. 2005. Larval fish assemblages in Independencia Bay, Pisco, Peru: temporal and spatial relationship. Marine Biology 147: 77-91.

Zuñiga H \& E Acuña. 1992. Larval development of two sympatric flounders, Paralichthys adspersus (Steindachner, 1867) and Paralichthys microps (Gunther, 1881) from the Bay of Coquimbo, Chile. Fishery Bulletin 90: 607-620. 